\title{
A Comparative Analysis of Physicochemical Composition of Selected Spring Water in the Bale Eco-region, South East Ethiopia
}

\author{
Getachew Meka ${ }^{1}$, Alemayehu Wudneh ${ }^{2}$ \\ ${ }^{1}$ School of Public Health, College of Medicine and Health Science, Hawassa University, Hawassa, Ethiopia \\ ${ }^{2}$ Department of Natural Resource Management, College of Agriculture and Natural Resources, Madda Walabu University, Robe, Ethiopia
}

Email address:

gmeka7209@gmail.com (G. Meka), alexokono@gmail.com (A. Wudneh)

\section{To cite this article:}

Getachew Meka, Alemayehu Wudneh. A Comparative Analysis of Physicochemical Composition of Selected Spring Water in the Bale Ecoregion, South East Ethiopia. International Journal of Atmospheric and Oceanic Sciences. Vol. 3, No. 2, 2019, pp. 36-40.

doi: $10.11648 /$ j.ijaos.20190302.12

Received: July 2, 2019; Accepted: July 26, 2019; Published: December 23, 2019

\begin{abstract}
Spring water chemical behaviors in various locations and environmental degradation are being among the most recent dynamic issues. In this study, spring water sources of the Rira and Burkitu streams of remote rural areas were considered as holy and healthy water by the local communities. However, the quality of the water is not yet analyzed and still very low attentions are paid by the concerned governmental stakeholders towards characterizing the mineral constituents in order to confirm the existing perceptions. This study focused on comparing water quality of two springs exists in the two extreme altitudinal difference (from upper mountain (Rira spring) and lower altitude (Burkitu spring)) flowing through undisturbed ecosystem in the Bale Ecoregion. Water samples were taken following depth integrated composite samples from the two streams in 2015. The samples were taken to Ethiopian Public Health Organization, Addis Ababa. The spring water samples' physicochemical characteristics were compared by one way ANOVA and a piper diagram and evaluated against WHO drinking water quality standards. Laboratory investigations revealed that "Burkitu" spring water has a special physique that makes it advantageous water. Turbidity, $\mathrm{PO}_{4}, \mathrm{~F}^{-}$, and $\mathrm{NH}_{4}{ }^{+1}$ content of Rira and Burkitu spring water were 0.11 and 1.06 (NTU), 0.08 and $0.1(\mathrm{mg} / \mathrm{L}), 0.43$ and $0.42(\mathrm{mg} / \mathrm{l}) 0.19$ and $0.18(\mathrm{mg} / \mathrm{l})$ but not significantly different at $\mathrm{P}$ value less than 0.05 in that order respectively. Significantly different parameters at $\mathrm{P}$ value less than 0.01 were filterable residue at $180^{\circ} \mathrm{C}, \mathrm{CaCO}_{3}$, Hardness, silica, $\mathrm{Na}^{+}, \mathrm{K}^{+}, \mathrm{Ca}, \mathrm{Mg}, \mathrm{NO}_{3}$, and $\mathrm{HCO}_{3}$ content of Rira and Burkitu springs were 56 and 222, 10 and 180, 36 and $188,28.18$ and 33.51, 6.1 and 8.2, 0.6 and 1.3, 11.22 and 54.51, 1.95 and 12.65, 6.17 and 1.19, 12.2 and 219.6 in that order respectively. $\mathrm{pH}$ and $\mathrm{NO}_{2}$ of the springs were significantly different at $\mathrm{P}$ value less than 0.05 . The most dominant hydro chemical facies explaining the quality were $\mathrm{Ca}$ and $\mathrm{Na}$ in which $\mathrm{Ca}^{2+}>\mathrm{Na}^{+}$. Moreover, the water fit Ethiopian drinking water standard saving the lives of those rural communities with low and cheap water treatment.
\end{abstract}

Keywords: Bale Ecoregion, Water Quality, Comparative, Spring Water

\section{Introduction}

Any civilized society should consider the provision of safe drinking water as a priority. This is so because safe drinking water is a basic need to human development, health and wellbeing [1]. Moreover, water is an essential resource for living system, industrial process, agricultural production and domestic use [2]. The use of water increases with growing population and economy, and intensive and extensive agriculture putting increasing strain on these water resources [3].
The quality of water needs evaluation to generate baseline data for welfare of the society as well as reduces the possible outbreak of water borne diseases, which is more common in developing countries. The first and a key, step in providing safe drinking water is the selection of the best available source of water without referring to its physicochemical and biological quality [4]. The quality of spring and small streams, running through rural areas, less known and even has not been properly evaluated for the intended use rather both animals and human beings can utilize the same water source without 
protection and many more rural communities live in water stress areas specially during the dry season in Ethiopia [5]. However, naturally spring water is better protected than surface water and even filters itself until gets saturated. Rain water or other water, such as from surface water infiltration that percolate into through the soil can harbor pathogens but these are effectively removed by attachment to soil particles, die-off and biological process [6].

Catchment protection is the other factor in providing safe drinking water for whatever reasons, source choice limited it presents a key opportunity to minimize pathogen contamination [7]. Water quality plays an important role for the safety of food particularly for infants. For the ground water source especially spring water that provides excellent water sources free of microbiological pollution however proper chemical composition can be used to minimize the risk of waterborne diseases in Ethiopia [8]. For infants, natural spring water and natural mineral water of low sodium concentration $\left(</=20 \mathrm{mg} / 1 \quad \mathrm{Na}^{+}\right)$and low mineralized $(</=500 \mathrm{mg} / 1)$ dissolved solids is recommended. Generally, water is one of the main dietary components but less due consideration is given in most developing countries. Its quality plays an important role for the safety of food particularly for infants [9].

In these study areas, most communities residing there were using Rira and Burkitu spring water as "holy" water. The purity of water, the belief in its known historical and unknown mythological origins, and the inaccessibility of remote sources, and lack of safe alternative water sources elevates its importance even further. However, there was no any information regarding the quality of the water and its mineral richness so far. Inaddition to these facts, due to personal perceptions and individual attitudes the rural community utilizes the water due to factors like economic, financial, social or environmental reasons [10]. In order to alleviate physicochemical water pollution a systematic study on types and concentration of nutrients at the water sources is required. Adding the common factors and cultural aspects in general, this study is to verify the hypothesis that water quality in small streams in rural areas of the Bale Goba zone, Oromia region has rich in mineral contents naturally and in some aspects which has even become worse in quality.

\section{Description of the Study Area}

The Bale Mountains Eco-region lies in Oromia Regional State in south-eastern Ethiopia between $50^{\circ} 22^{\prime}-80^{\circ} 08^{\prime} \mathrm{N}$ and $38^{\circ} 41^{\prime}-40^{\circ} 44^{\prime} \mathrm{E}$. The Bale Ecoregion comprises attractive and unique biodiversity and national park. The peak altitude of the area is characterized by a high plateau (Afro-alpine habitat) much of which is above $3000 \mathrm{~m}$ asl and continuously rise from this plateau to TulluDimtu $(4377 \mathrm{~m})$, the second highest peak in Ethiopia. Moist tropical Harenna Forest with several altitudinal vegetation stratification within short distances starting with mountain grasslands at approximately $3700 \mathrm{~m}$, followed by Erica forest, and extending to moist tropical forests of variable species composition such as highland bamboo (Arundinariaalpina), Coffeaarabicaand others at the middle altitude, and dryland woodlands in the lowlands below $1500 \mathrm{~m}$ asl [11].

About 1.6 million populations is inhabited in the ecoregion and moreover around 12 million population both in the eco-region and beyond within Ethiopia, Somalia and Kenya are expected to directly and indirectly depend on several ecosystem services of the forests of the Bale ecoregion. More than 40 springs and streams rise in the Bale Mountains that feed five major rivers in the eco-region namely the Web, Wabi Shebelle, Welmel, Dumal and Ganale. Rira stream starts flowing from an altitude of $3979 \mathrm{~m}$ asl while Burkitu stream flows down ward from an altitude of $1456 \mathrm{~m}$ asl [12].

\section{Laboratory Methods}

Water samples were collected in the field in November 2015 as per environmental sampling and analysis guideline [13]. At each sampling site, measurements were made for temperature, specific conductivity, and $\mathrm{pH}$ of the waters. The $\mathrm{pH}$ of each sample was measured using a portable $\mathrm{pH}$ meter with automatic temperature compensation. The $\mathrm{pH}$ meter was calibrated using three standard buffers with nominal $\mathrm{pH}$ values of $7.00,4.01$, and 10.00 at $25^{\circ} \mathrm{C}$. At each subsequent step during the day, the $\mathrm{pH}$ calibration was checked by measuring the $\mathrm{pH}$ of one of the standard buffers. Resulting values were always within $\pm 0.05 \mathrm{pH}$ units of the accepted value. The accuracy of each sample $\mathrm{pH}$ measurement is probably also within this range. Specific conductivity was measured using a portable temperature-compensated probe, sensitive to within \pm 10 microsiemens $/ \mathrm{cm} \quad(\mu \mathrm{S} / \mathrm{cm})$ and accurate to within $\pm 20 \mu \mathrm{S} / \mathrm{cm}[14]$.

Anion samples were filtered through $0.45 \mu \mathrm{m}$ nominal pore-diameter cellulose acetate filters and refrigerated with no further treatment. Cation samples were filtered through the same $0.45 \mu \mathrm{m}$ filter and acidified by adding $2 \mathrm{~mL}$ of concentrated ultra-pure nitric acid to per $1000 \mathrm{~mL}$ sample [15]. Samples for alkalinity analyses were collected by filling a $125 \mathrm{~mL}$ bottle, without filtering or acidification samples were then refrigerated. The samples were filtered through $0.45 \mu \mathrm{m}$ filters after sample collection. For every sample type except alkalinity, field blanks were collected using deionized water that was brought from the laboratory and treated as a sample in the field.

This procedure helped assure the purity of reagents used for sample preservation, as well as assuring that the samples were not contaminated during collection. In every case, analyses of field blanks showed below detection concentrations for all constituents.

Upon completion of field work samples were kept cool at $4^{\circ} \mathrm{C}$ during transport in insulated containers, the analyses were made in the Ethiopian Public Health Institute research laboratory. The sampling bottle was first washed three times with water prior to the collection into $2000 \mathrm{ml}$ polythene bottle. The following parameters were selected to be determined: nitrate $\left(\mathrm{NO}_{3}{ }^{-}\right)$, phosphates $\left(\mathrm{PO}_{4}{ }^{3-}\right)$, fluoride $\left(\mathrm{F}^{-}\right)$, chloride $\left(\mathrm{Cl}^{-}\right)$, sulphate $\left(\mathrm{SO}_{4}{ }^{2-}\right)$, total dissolved solids (TDS), total suspended solids (TSS), total hardness, sodium $\left(\mathrm{Na}^{+}\right)$, 
potassium $\left(\mathrm{K}^{+}\right)$, calcium $\left(\mathrm{Ca}^{2+}\right)$, magnesium $\left(\mathrm{Mg}^{+2}\right)$, bicarbonate $\left(\mathrm{HCO}_{3}{ }^{-}\right)$and carbonate $\left(\mathrm{CO}_{3}{ }^{2-}\right)$, water acidity $(\mathrm{pH})$ and conductivity. All in-lab analyses adhered to strict quality assurance/quality control protocols. A blank sample was run at the beginning of each tested parameter, followed by a standardized QA/QC sample and a repeat of the succeeding field sample. Each of the tests followed Standard Methods for the Examination of Water and Wastewater [16].

Metal samples were analysed using Flame Atomic Absorption Spectrophotometer (FAAS) for $\mathrm{Ca}, \mathrm{K}, \mathrm{Mg}$, and $\mathrm{Na}$. Only those elements that were above detection limits were included in the results. The preferred method to compute total hardness was taken from the results of separate ion determinations of calcium and magnesium as $\mathrm{mg} / \mathrm{L}$ of $\mathrm{CaCO}_{3}$; TDS and TSS by gravimetric method [17]. Sulfate, fluoride, nitrate and phosphate were analyzed using a UVVis-NIR Varian Spectrophotometer, based on a method outlined by the United States Environmental Protection Agency [18]. The obtained results were assessed in accordance with Ethiopian drinking water guidelines.

\section{Results and Discussion}

This study assessed the physicochemical parameters of the Rira and Burkitu stream water samples collected from two different geographical extremes, during the month of November 2015 and the water quality results of the spring water samples are presented in Table 1. The Burkitu and Rira spring water $\mathrm{pH}$ values are between 7.31 and 8.05 respectively; these alkaline values might be represented as a result ofweathering of the volcaniclastic rocks, with possible contributions by dissolution ofcarbonates and bicarbonates from geological formations [19]. It is observed that all the samples are above the permissible limit of 6.5 , and within the desirable limit of 8.5 suggested by Federal Democratic Republic of Ethiopia Ministry of Health for drinking water standard [20]. The increase in $\mathrm{pH}$ might be resulted from atmospheric contribution, decomposition of decayed organic matter and anthropogenic causes. The relatively high $\mathrm{pH}$ of the spring would favor precipitation of a mineral phase (goethite or amorphous $\mathrm{Fe}(\mathrm{OH})_{3}$ ), thus controlling the concentration of $\mathrm{Fe}$.

Electrical Conductivity (EC) Burkitu and Rira spring water were 357 to 86.7 at $25^{\circ} \mathrm{C}$; TDS varies from 222.00 to 56.0 $\mathrm{mg} / \mathrm{L}$ respectively. The EC observed were within the permissible limit of $750 \mu \mathrm{S} / \mathrm{cm}[21]$ in the two locations. Total dissolved solids were also within the permissible limit of 500 $\mathrm{mg} / \mathrm{L}$. Generally, water containing less than $500 \mathrm{mg} / \mathrm{L}$ of total dissolved solids is considered as fresh water category so that it is potable but after it was validated by local government with necessary follow up of water quality.

The $\mathrm{Ca}^{2+}$ concentration is found in Rira to be low as 11.22 $\mathrm{mg} / \mathrm{L}$ whereas in Burkitu spring it was observed as high concentration $54.51 \mathrm{mg} / \mathrm{L}$. The permissible limit of $\mathrm{Ca}^{2+}$ for drinking water is specified as $75 \mathrm{mg} / \mathrm{L}$ [22], so the samples were within the permissible limit. The $\mathrm{Mg}^{2+}$ concentration varies from $12.65 \mathrm{mg} / \mathrm{L}$ (Burkitu) to $1.95 \mathrm{mg} / \mathrm{L}$ (Rira) and the limit of $\mathrm{Mg}^{2+}$ for drinking water is $30 \mathrm{mg} / \mathrm{L}$ [23], this can also be implies that, the samples were within in the permissible limit. The $\mathrm{Na}^{+}$concentration in Burkitu and Rira varies from $8.20 \mathrm{mg} / \mathrm{L}$ to $6.10 \mathrm{mg} / \mathrm{L}$. This value agrees with the permissible limit of $\mathrm{Na}^{+}$for drinking water is specified as $200 \mathrm{mg} / \mathrm{L}$ [20], and all are within the permissible limit. The $\mathrm{K}^{+}$concentration of the spring water was not detected, evethough, the permissible limit of $\mathrm{K}^{+}$for drinking water is specified as $50 \mathrm{mg} / \mathrm{L}$ [21].

Moreover, the bicarbonate concentration in Burkitu is $219.60 \mathrm{mg} / \mathrm{L}$ whereas it was $12.20 \mathrm{mg} / \mathrm{L}$ in Rira water sample which was probably as a result of geological formation of the area (Table 1).

Table 1. Physico-chemical parameters of Burka and Rira spring water in $m g / L$.

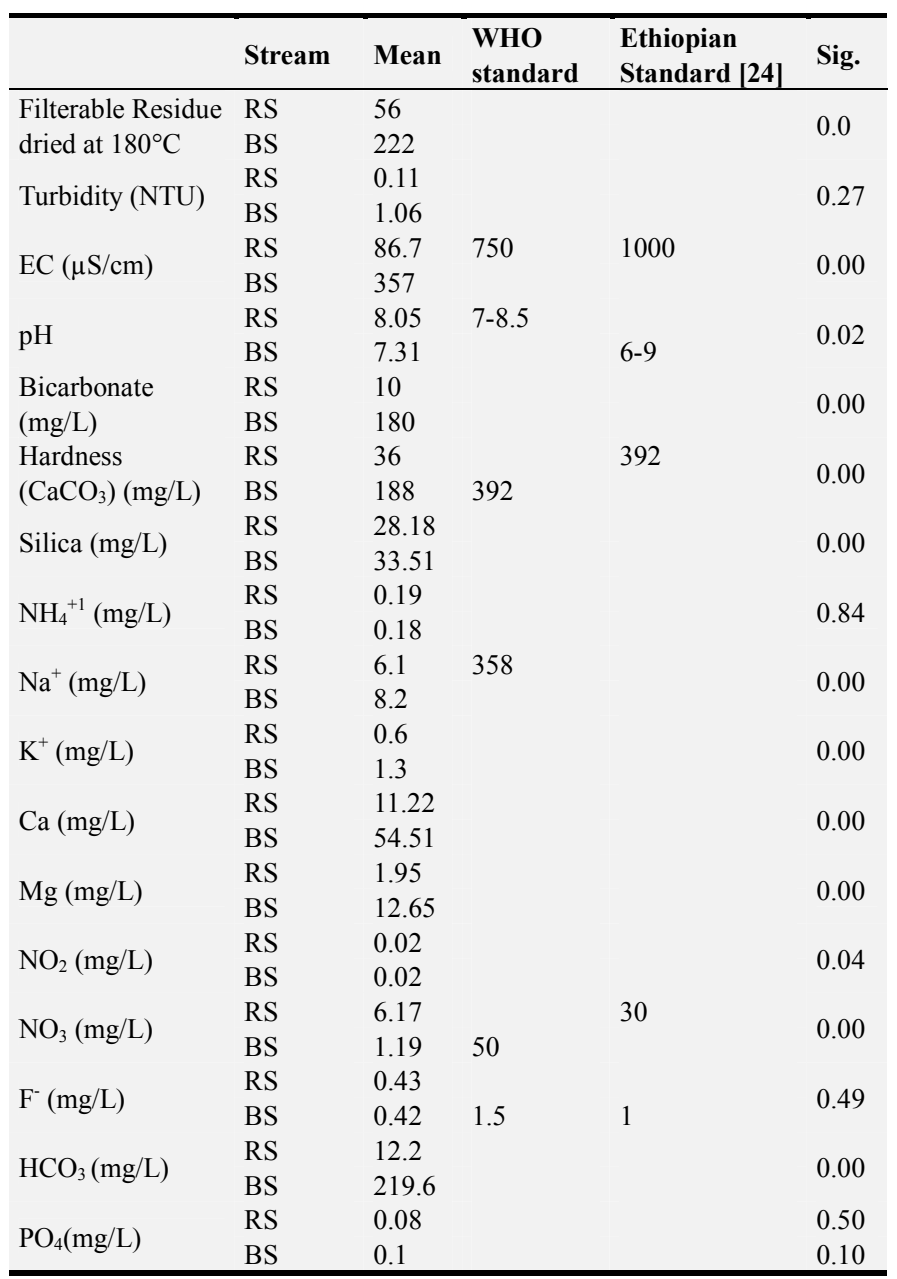

RS: Rira Stream, BR: BurkituStream*EC is expressed in $\mu \mathrm{S} / \mathrm{cm}$; ** $\mathrm{pH}$ - in $\mathrm{pH}$ meter

\subsection{Comparative Water Quality of "Highland" and “Lowland" Samples and Chemical Relationships}

Piper's Trilinear diagrams are very useful in bringing out the chemical relationships of spring or ground waters in more definite terms [25]. It identifies hydro-chemicalfacies by plotting the chemical composition of water in a central diamond-shaped diagram in which all the four sides are 
defined by the proportions of major ions in water. In the present study, the major cations and anions of water samples have been plotted with Piper Trilinear diagram (Figure 1)[26]. The plotted samples were distributed in sector 6 of

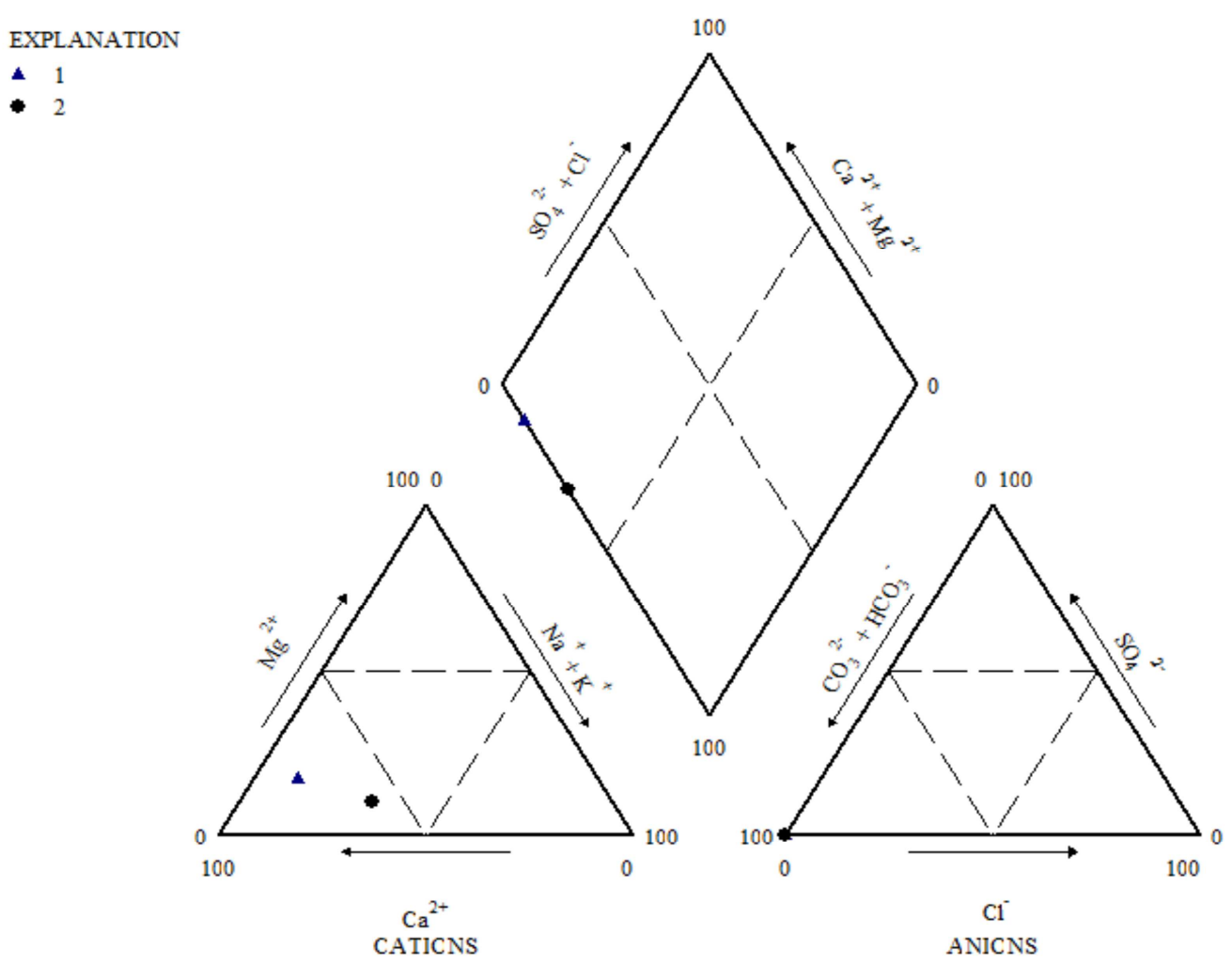

Figure 1. Piper Plot. the diamond-shaped field which indicates that non-carbonate exceeds $50 \%$. The hydro geochemical facies of the water samples are as $\mathrm{Ca}^{2+}>\mathrm{Na}^{+}$and $\mathrm{Cl}^{-}>\mathrm{SO}_{4}{ }^{2-}$ facies.

\subsection{Comparison with Standards}

To estimate whether the spring water of the study area is suitable for drinking purposes, it has been compared with the standards of WHO and Ethiopian standard guidelines [22]. The samples were analysed and compared with the prescribed standards, and the result are presented in Table 1. Among the samples, considerable numbers of samples were identified with the desirable limits of the standards of drinking purposes. Nevertheless, more than $80 \%$ of the samples have shown within the permissible limit of Ethiopian and WHO standard for drinking water.

\section{Conclusion}

In Ethiopia, drinking water is obtained from several sources including unprotected boreholes and surface water, as well as ground water from wells, more recently bottled water has been gaining popularity. The results revealed that the spring water source of this area is fresh water type and the studied parameters were within permissible level and free of pollution as prescribed by WHOat all the sampling stations. The sequence of abundance of the major ions is $\mathrm{Ca}^{2+}>\mathrm{Mg}^{2+}>\mathrm{Na}^{+}>\mathrm{K}^{+}$and $\mathrm{HCO}_{3}{ }^{-}>\mathrm{F}^{-}$moreover, from Piper's Trilinear diagrams the hydro geochemical facies of the water samples were presented as $\mathrm{Ca}^{2+}>\mathrm{Na}^{+}$and $\mathrm{Cl}^{-}>\mathrm{SO}_{4}{ }^{2-}$ facies. The fact thatspringwater is received from precipitations, ionic concentration by ionicBase Exchange and geological formation can be less significant from the measured results. Results of the hydrochemistry suggest that, the two spring water samples were alkaline in nature. Furthermore, the small or insignificant concentration of $\mathrm{NO}_{3}{ }^{-}, \mathrm{PO}_{4}{ }^{3-}$ and $\mathrm{Cl}^{-}$is an indication that the catchment of the area is healthy and protected. Moreover, total hardness, electrical conductivity, and total suspended solids were highest in Burka spring water (low land area) than Rira. Generally, the comparative analysis suggests the distinct nature ofdifferentspring water and it depends on geographical location, and geological foundation. Comparatively Burka spring water was rich in mineral content than Rirastream. This study wouldhelp to create and develop awareness among the people tomaintain the quality of the river waters.

\section{Conflicts of Interest}

The authors declare that there are no conflicts of interest.

\section{Acknowledgements}

We thank to the crews of Ethiopian Public Health Laboratory, Addis Ababa in analyzing water samples. The authors would like to thank Kono Environmental Consulting PLC for financial support. 


\section{References}

[1] B. State, M. B. Nkamare, A. N. Ofili, A. J. Adeleke, and M. B. Nkamare, "Physico-chemical and microbiological assessment of borehole water in," vol. 3, no. 5, pp. 2549-2552, 2012.

[2] A. A. Bullock et al., "Chapter 1 Getting out of the box linking water to decisions for sustainable development," pp. $3-23$.

[3] W. P. Parte and H. Editorchief, of Environmental Chemistry Editor-in-Chief.

[4] P. H. Gleick, "The human right to water," Water Policy, vol. 1, no. April 2011, pp. 487-503, 1999.

[5] A. S. Ademe and M. Alemayehu, "Intellectual Properties Rights: Open Access Source and Determinants of Water Pollution in Ethiopia: Distributed Lag Modeling Approach," vol. 2, no. 2, 2014.

[6] F. D. Vall and C. J. Faur, "No Title," pp. 77-79.

[7] A. Iii and A. P. Nap, "THE FEDERAL DEMOCRATIC REPUBLIC OF ETHIOPIA ENVIRONMENTAL PROTECTION AUTHORITY THE 3 rd NATIONAL REPORT ON THE IMPLEMENTATION OF THE UNCCD / NAP IN ETHIOPIA,” no. February, 2004.

[8] D. A. Groups et al., "Holy water qualty and physichochemical characterstics", Anal. methods, 2002.

[9] J. Scanlon and A. Cassar, Water as a Human Right? Water as a Human Right?, no. 51.

[10] T. Facon, J. Margat, T. Le-huu, and J. M. Trondalen, "Key messages," pp. 150-159.

[11] B. Eco-region, "Watershed Development Options in the," no. 2.

[12] F. Africa, "Bale Mountains Eco-region Reduction of Emission from Deforestation and Forest Degradation (REDD +) Project-," 2014.
[13] E. P. Authority, "Groundwater sampling guidelines," no. April, 2000.

[14] D. H. Consultants, "wells for water quality analysis," no. May, 1999.

[15] Perkin Elmer Coorporation, "Analytical Methods for Atomic Absorption Spectroscopy," Anal. Methods, p. 216, 1996.

[16] W. E. Federation, "Standard Methods for the Examination of Water and Wastewater Part 1000 Standard Methods for the Examination of Water and Wastewater," 1999.

[17] C. C. Zhang, Fundamentals of Environmental Sampling and Analysis.

[18] U.S. Agency for International Development, "Water and development," pp. 1-33, 2013.

[19] D. Chapman, "Water Quality Assessments - A Guide to Use of Biota, Sediments and Water in Environmental Monitoring Second Edition Edited by," 1996.

[20] "National Drinking Water Quality Monitoring and Surveillance Strategy May 2011 Addis Ababa," no. May, 2011.

[21] H. G. Gorchev and G. Ozolins, "WHO guidelines for drinking-water quality.," WHO Chron., vol. 38, no. 3, pp. 104-108, 2011.

[22] F. Addendum and T. O. Third, "Guidelines for Drinking-water Quality," vol. 1.

[23] F. Goreth, Canadian holy water quality standards, Table of Contents, 1996.

[24] M. Of and W. Resources, "ETHIOPIAN GUIDELINES SPECIFICATION FOR,” no. September, 2002.

[25] G. Survey, "Ground Water and the Rural Homeowner."

[26] D. Hem, "Study and Interpretation the Chemical of Natural of Characteristics Water," Text, vol. 2254, no. 2254, p. 263, 1985. 